\title{
ANALYTICAL AND EXPERIMENTAL STUDY OF WATER SEEPAGE PROPAGATION BEHAVIOR IN THE FAULT
}

\author{
Zhen HUANG ${ }^{1)}$, Zhen-Quan JIANG ${ }^{1)}{ }^{*}$, Zi-Wei QIAN ${ }^{1)}$ and Ding-Tao CAO ${ }^{2)}$ \\ 1) School of Resources and Earth Science, China University of Mining and Technology, Xuzhou, Jiangsu 221116, China \\ 2) Yanzhou Coal Mining Co., Ltd., Yanzhou Coal Mining Company, Zoucheng 273500, China \\ *Corresponding author's e-mail: zqjcumt@126.com
}

\begin{tabular}{l} 
ARTICLE INFO \\
\hline Article history: \\
Received 12 May 2014 \\
Accepted 22 September 2014 \\
Available online 6 October 2014
\end{tabular}

Keywords:

Water inrush through fault

Water seepage

Impermeability

Water injection test

Initial water seepage pressure

Initial hydraulic conductivity

\begin{abstract}
Coal mine water inrush has an impartible relationship with the fracture zone such as faults, which deeply threaten the safety production in China. In order to study the water seepage behavior in the fault and the impermeability of the fault when water inrush through fault occurs, some water inrush cases through faults were analyzed, and water injection tests which drilled one injection borehole and one observation borehole into the fault zone were carried out at one coal mine. The breakdown pressure, reopening pressure, as well as the initial water seepage pressure, impermeability and the initial hydraulic conductivity of Puzizhier fault, were obtained from the result of the water injection tests. The study shows that water seepage in faults goes through three stages which consist of pore flow, fracture flow and pipe flow. It shows a process of the fine particulates and existing in-fill in the fault zone washing out and original and newborn cracks expanding and connecting. The results of water injection tests can be thought to show the fault healing effect under the underground pressure. In addition, the risk of water inrush through faults owes a great deal to the characteristic of water source.
\end{abstract}

\section{INTRODUCTION}

Coal mine workers' safety and coal production have been deeply threatened by coal mine water inrush accidents (Meng et al., 2012), and the accidents frequently occur according to the latest statistics in China (Wang et al., 2012). It has been proved that the majority of the water inrush accidents are related with the fracture zone and its proportion is more than $80 \%$ (Bu et al., 2009; Li et al., 2010; Xu, 2011; Qiao et al., 2013; Lu et al., 2013). Furthermore, the water seepage behavior in the fault is an important parameter for deep coal mining.

In order to study the behavior of water seepage in the fracture zone, especially in faults, researchers have done numerous positive and beneficial researches (Yang, 1994; Li et al., 1996; Shi et al., 2001; Wu et al., 2002; Wu et al., 2004; Liu et al., 2007; Lu et al., 2013). Moreover, the phenomenon is noted that most water inrush accidents through faults delayed in time (Zhou et al., 2000; Wu et al., 2003; Li et al., 2010; Xu, 2011; Qiao et al., 2013). In terms of water seepage in faults, the current researches are far from satisfactory, and the study of the impermeability of faults keeps at a preliminary stage.

In general, water seepage in faults and the impermeability of faults are studied by laboratory tests, numerical analysis and theoretical analysis (Zhou et al., 2000; Wu et al., 2003; Zhou et al., 2008; Li et al., 2010; Qiao et al., 2013). But those methods have difficulties in obtaining the true and accurate results due to the complex field conditions. Conversely, the field measurements, such as water injection test (Wu et al., 2003; Jiang et al., 2007; Kitagawa et al., 2007; Mukai et al., 2007), are more useful and preferable. Up to now, water injection test is rarely using in coal mines (Wu et al., 2003), especially in faults. In this paper, the result and the analyses of the water injection tests and some water inrush cases in the coal mine are presented. Research on studying the water seepage propagation behavior in faults and the impermeability of faults, some water inrush cases through faults were analyzed and water injection tests were carried out in Xinglongzhuang coal mine.

\section{A CASE STUDY \\ 2.1. ACCIDENT OUTLINE}

On August 17, 2010, at 23:23, a water inrush accident occurred at No. 8602 heading face of Tianzhuang coal mine in Yanzhou city, Shandong Province, China. Fortunately, nobody was injured or dead. The Tianzhuang coal mine, situated in Yanzhou, Eastern China, is a middle modern coal mine, which was constructed in 1997 and put on production on November 18st, 2002 (Fig. 1). Tianzhuang coal mine is mining the Permo-Carboniferous coal seams. 18 coal seams of Permo-Carboniferous coal seams are named No. 1 to No. 18 coal seam from top to bottom. Its production capacity is 0.9 million tons and the main minable coal seams include No. 16 and No. 17 coal seam whose thickness varies from 0.9 to $1.3 \mathrm{~m}$.

The No. 8602 working face is situated in the middle of the No. 8 mining district. The No. 8602 working face's middle gateway was driving along the No. 16 coal seam with an average rising dip angle of $11^{\circ}$. On August 17, 2010, at 23:23, a water inrush with a flow rate of $3 \mathrm{~m}^{3} / \mathrm{h}$ occurred at the time of disclosing the No. 4 fault (Fig. 2). The flow rate rose 


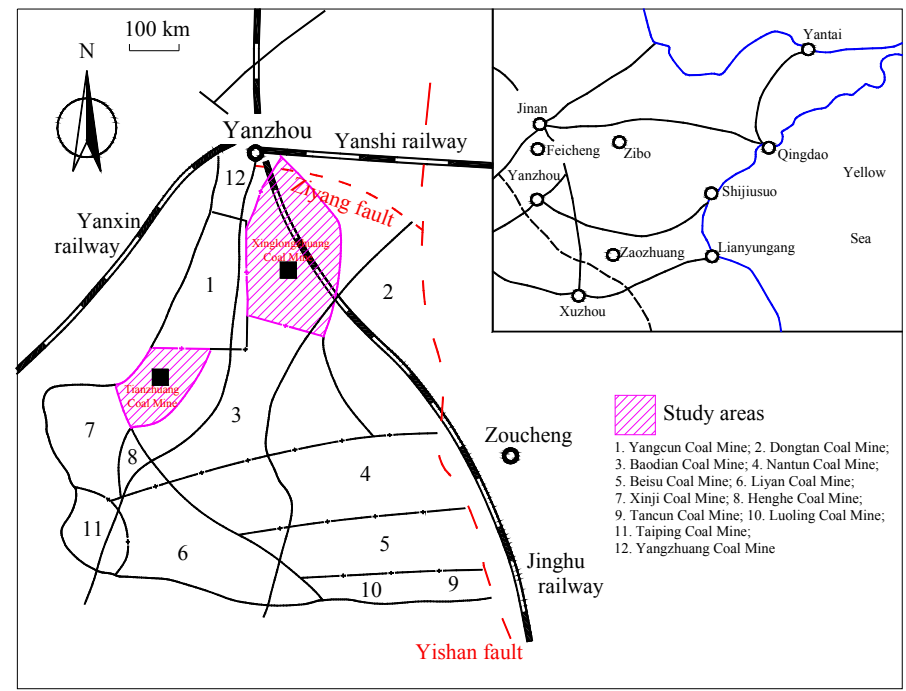

Fig. 1 Geographical position of study areas.

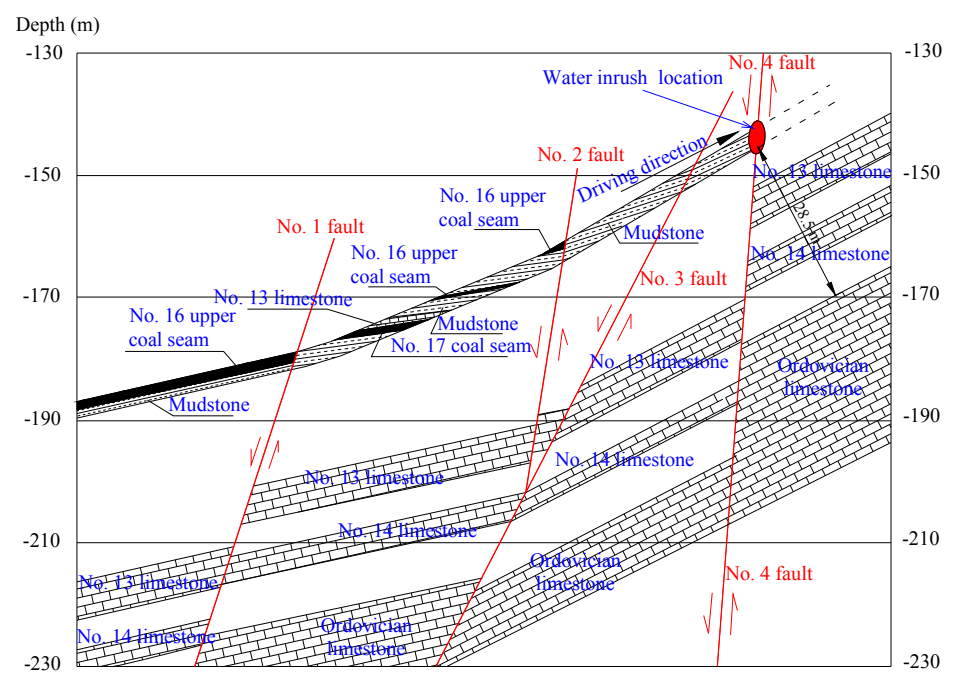

Fig. 2 Top view of geological section map and the location of water inrush point.

up rapidly after that time, and the flow rate had accordingly increased nearly 110 times which increased from $12 \mathrm{~m}^{3} / \mathrm{h}$ at $00: 30$, August 18,2010 to $1296 \mathrm{~m}^{3} / \mathrm{h}$ at 17:26, August 19, 2010. Then, the flow rate dropped back to be about $900 \mathrm{~m}^{3} / \mathrm{h}$ at $05: 00$, August 20, 2010 (Fig. 3). Moreover, water quality test result shows that it came from Ordovician aquifer. There is no doubt that the water inrush accident must be associated with the fault. As shown in Figure 2, three aquifers which include No. 13 limestone aquifer, No. 14 limestone aquifer and Ordovician limestone aquifer exit under the floor of the working face. Furthermore, defining the water source of the inrush accident is necessary and important. According to the hydrologic observation wells in Tianzhuang coal mine, the water level in an Ordovician hydrologic observation well which was about 1 kilometer apart from the water inrush point dropped $8 \mathrm{~m}$ during the water inrush accident, while the water levels in No. 13 and No. 14 limestone observation wells had not changed. Under these conditions mentioned above, the water inrush accident occurred owing to that water from Ordovician limestone aquifer gushed to the gateway through the fault.

\subsection{ANALYSES OF THE FAULT WATER INRUSH ACCIDENT}

More information can be obtained from the changing inflow during the water inrush accident (Fig. 3). For the next 30 hours after the beginning, the flow rate increased slowly, especially in the initial 14 hours. Then, from 30 to 42 hours, the flow rate rose up rapidly which increased to the maximum value in this stage. After 42 hours, the flow rate remained stable for some hours and then decline. As a consequence, we can get the information that the growing of water inrush channels would take some hours. Some water inrush accidents cases through faults in China (Feng et al., 2004; Li et al., 2006; Li et al., 2010; Zheng et al., 2010) were collected and 


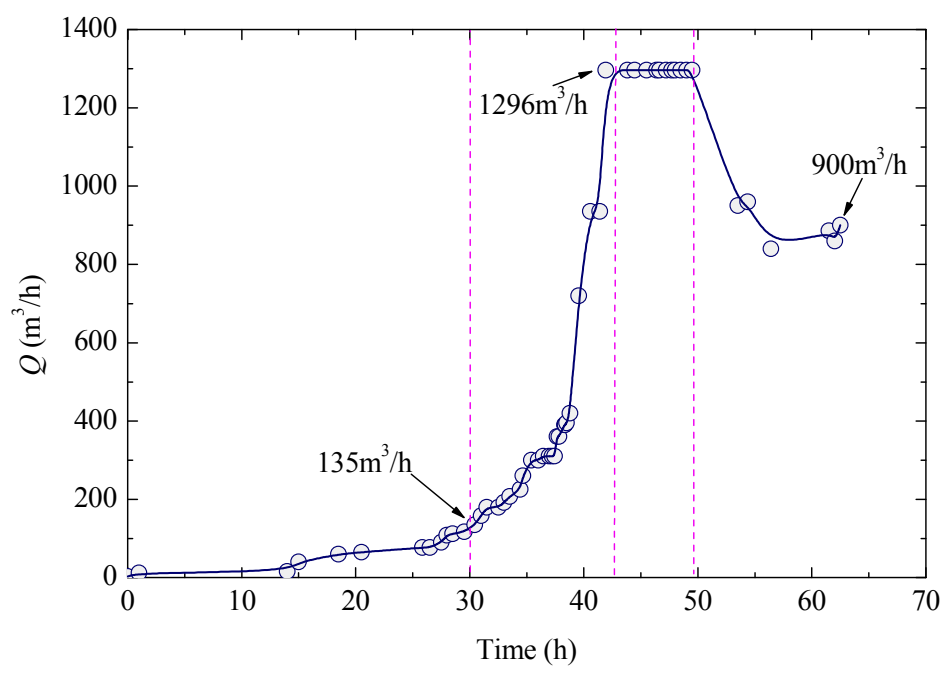

Fig. 3 Flow rate $(Q)$ distribution at the middle gateway.

Table 1 Fault water inrush accidents in China (Feng et al., 2004; Li et al., 2006; Li et al., 2010; Zheng et al., 2010).

\begin{tabular}{|c|c|c|c|c|c|c|}
\hline No. & $\begin{array}{l}\text { Coal mine } \\
\text { name }\end{array}$ & Year & $\begin{array}{c}\text { Initial water } \\
\text { inflow } \\
\left(\mathrm{m}^{3} / \mathrm{h}\right) \\
\end{array}$ & $\begin{array}{l}\text { Maximum water } \\
\text { inflow }\left(\mathrm{m}^{3} / \mathrm{h}\right)\end{array}$ & $\begin{array}{l}\text { Lag time of the } \\
\text { maximum water } \\
\text { inflow }\end{array}$ & Water source \\
\hline 1 & Wangfeng & 1973 & 12 & 1020 & $48 \mathrm{~h}$ & Ordovician aquifer \\
\hline 2 & Fengying & 1973 & 54 & 1620 & $48 \mathrm{~h}$ & $\begin{array}{l}\text { No. } 3 \text { limestone } \\
\text { aquifer }\end{array}$ \\
\hline 3 & Taoyang & 1985 & 276 & 6420 & $120 \mathrm{~h}$ & Ordovician aquifer \\
\hline 4 & Yangzhuang & 1985 & 600 & 4000 & $8 \mathrm{~h}$ & Ordovician aquifer \\
\hline 5 & Yangzhuang & 1988 & 59.8 & 3153 & $22 \mathrm{~d}$ & Ordovician aquifer \\
\hline 6 & Liuzhuang & 1993 & 91 & 251.5 & $96 \mathrm{~h}$ & $\begin{array}{l}\text { No. } 3 \text { limestone } \\
\text { aquifer }\end{array}$ \\
\hline 7 & Lincheng & 1995 & 450 & 2520 & $36 \mathrm{~h}$ & $\begin{array}{l}\text { Taiyuan group } \\
\text { limestone aquifer }\end{array}$ \\
\hline 8 & Sunzhuang & 1996 & 900 & 2400 & $50 \mathrm{~min}$ & Ordovician aquifer \\
\hline 9 & Lugou & 1997 & 5 & 2650 & $96 \mathrm{~h}$ & Ordovician aquifer \\
\hline 10 & Dongtan & 1999 & 6 & 570 & $16 \mathrm{~d}$ & $\begin{array}{l}\text { Jurassic sandstone } \\
\text { aquifer }\end{array}$ \\
\hline 11 & Dongtan & 2001 & 25 & 135 & $8 \mathrm{~d}$ & $\begin{array}{l}\text { Jurassic sandstone } \\
\text { aquifer }\end{array}$ \\
\hline 12 & Sanhejian & 2002 & 20 & 2170 & $6.5 \mathrm{~h}$ & Ordovician aquifer \\
\hline 13 & Liangzhuang & 2003 & 0.5 & 772.2 & $79 \mathrm{~d}$ & Ordovician aquifer \\
\hline 14 & Jinzhuang & 2004 & 8 & 3000 & $48 \mathrm{~h}$ & $\begin{array}{l}\text { Jurassic sandstone } \\
\text { aquifer }\end{array}$ \\
\hline 15 & Tianzhuang & 2010 & 3 & 1296 & $42 \mathrm{~h}$ & Ordovician aquifer \\
\hline
\end{tabular}

analyzed from literature and accident data (Table 1). Although they are not all in the study area, they still can be used to analyze the fault water inrush accident. The phenomenon that the time of the maximum water inflow lagged can be obtained from Table 1. From the viewpoint of water seepage in faults, three stages (Fig . 4) of water inrush through the fault may be summarized as the water seepage propagation behavior: first pore flow $(\mathrm{OA})$, second fracture flow $(\mathrm{AB})$, finally analogous pipe flow (BC) (Li et al., 2010; Qiao et al., 2013). In the first stage of water inrush, water flows through pore structure of fracture zone or the small original cracks, and the flow rate is low. Then the flow rate rises up rapidly as a result of the washout of fine particulates and existing in-fill in the fracture zone, the porosity of the fault changes and connective cracks appear in the second stage (Barbara et al., 2011; Bai et al., 2013). With the expanding and connecting of cracks, water seepage will turn into a kind of analogous pipe flow and will result in a large scale water inrush (Fig. 4). 


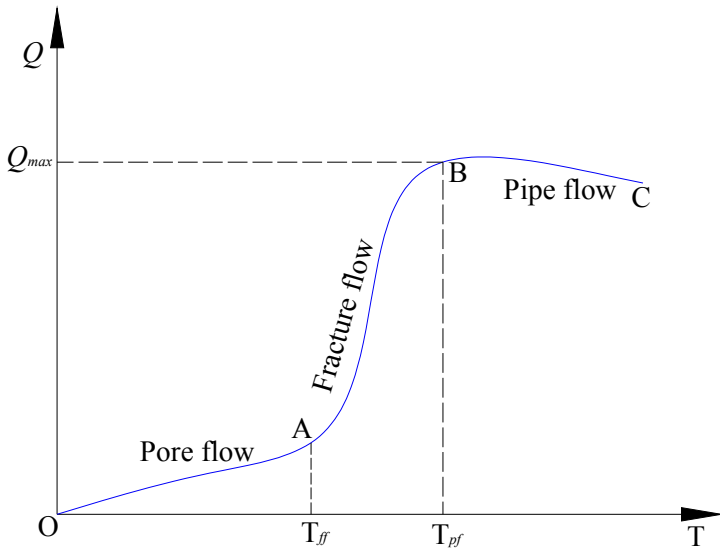

Fig. 4 Three stages of water inrush through faults.

\section{WATER INJECTION TESTS}

\subsection{STUDY AREA}

Xinglongzhuang coal mine which is closed to Tianzhuang coal mine, situated in Yanzhou, Eastern China, is a large modern coal mine (Fig. 1). It was formally put on production on December 21st, 1981 and its production capacity is 3 million tons. Nowadays Xinglongzhuang coal mine is mining the No. 3 coal seam, and will mine the deep No. 16 and No. 17 coal seams quickly with the decrease of the shallow coal seam. Water inrush from floor threatens the deep coal seams production due to the close distance between the aquifers and the No. 16 and No. 17 coal seams. Especially, the risk of water inrush is higher near faults. Therefore, water seepage behavior in faults was studied using water injection tests. Furthermore, the impermeability of Puzizhier fault was obtained from the result of tests.

Puzizhier fault has a nearly north-south strike and a dip angles of $60^{\circ}-80^{\circ} \mathrm{W}$. Test site is beside the Puzizhier fault outcrop area of inclined shaft. According to the drilling data, the distance between the fault outcrop position and the No. 10 lower limestone aquifer is approximately $25 \mathrm{~m}$ (Fig. 5).

\subsection{TEST METHOD}

Water seepage propagation behavior in the fault and the impermeability of faults are measured in boreholes by drilling two boreholes, of which one borehole was used to inject water and the other borehole was used to monitor water pressure (Fig. 5). The water injection test method in this work is illustrated in Figure 6. Nowadays, the packer test is used to be the usual tool for hydro-geological testing in boreholes (Guo et al., 2003; Hamm et al., 2007; Cheng et al., 2009; Quinn et al., 2011). But it is difficult to install in coal mines sometimes due to the complex conditions, e.g., site conditions in the underground tunnel, construction conditions and geological conditions (Huang et al., 2014). In order to solve the problem and carry out the water injection test easily, the method as follow was used in this study. As shown in Figure 6, as soon as the boreholes are drilled, casing pipes are installed in the boreholes from top to the vicinage of the fault zone in order to seal off the test section from other parts. The pressure measuring sensor is installed in the fault zone, and the sensor is connected with the pressure measuring instrument by cables through sealing coil. On the other hand, the injection borehole is connected with a pump. In addition, the flow meter and pressure gauge are fixed. Flanges are used to seal off the boreholes at last. Under these conditions, water can be injected into the test section and the test can be carried out.

As shown in Figure 5, two boreholes (Br-1 and Br-2) were both drilled into the fault zone, with a depth of $15.6 \mathrm{~m}$ and $20.8 \mathrm{~m}$, respectively. Two boreholes were made with an inclination of $32^{\circ}$ with the inclined shaft. Br-2 was injection borehole, while $\mathrm{Br}-1$ was observation borehole. $\mathrm{Br}-1$ and $\mathrm{Br}-2$ was $6.5 \mathrm{~m}$ apart. Br-1 and fault outcrop in the inclined shaft was $18.5 \mathrm{~m}$ apart.

The equipments used in this study mainly involved a pressure measuring sensor, a pressure measuring instrument and water injection equipments (Fig. 6). The pressure measuring sensor can observe

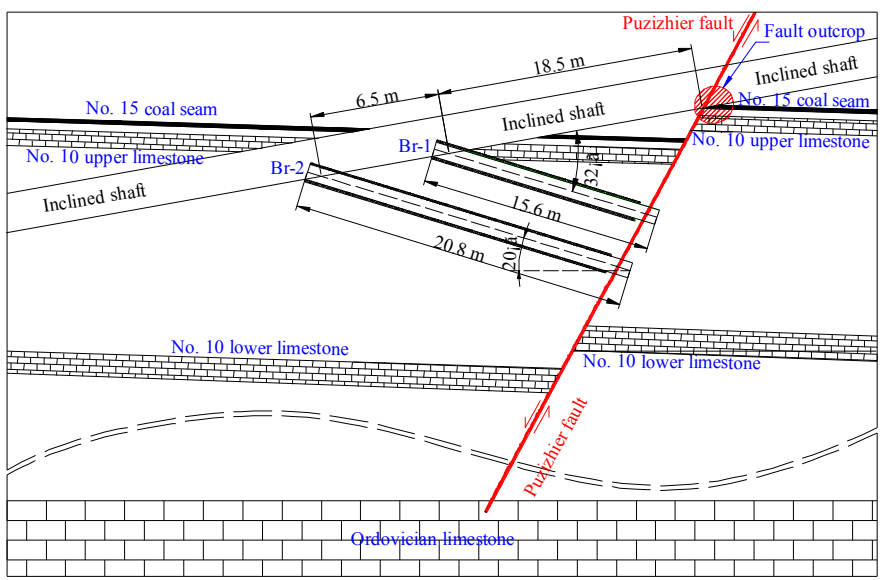

Fig. 5 Schematic section diagram of the test position and the design of two boreholes. 


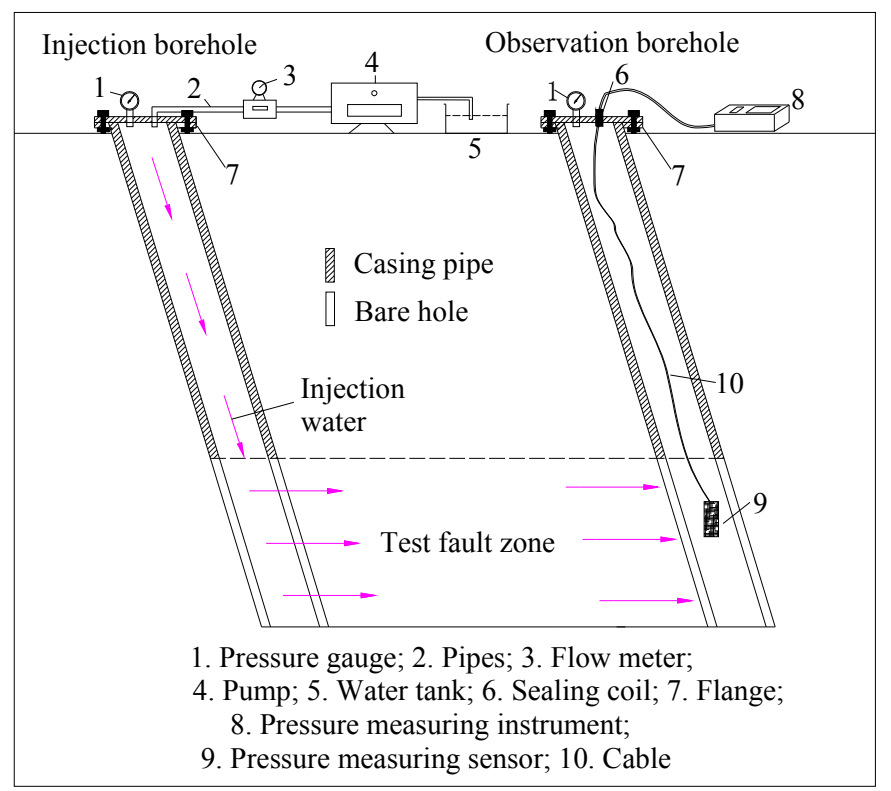

Fig. 6 Schematic diagram of the water injection test method.

the changing water pressure with a range from 0 to $6 \mathrm{MPa}$. The pressure measuring instrument is easy to take and suitable for underground working, and it can monitor the water pressure of the sensor in time. The water injection equipments involve a high pressure pump with a rated pressure of $22 \mathrm{MPa}$ and high pressure pipes and a water tank.

\subsection{TEST PROCEDURE}

After the test site had been selected, water injection tests were conducted in the following stages.

(1) All the pipes were checked at a pressure not greater than $15 \mathrm{MPa}$ to ensure that no leakage occurred before the water injection test.

(2) $\mathrm{Br}-1$ and $\mathrm{Br}-2$ were drilled to the vicinage of fault zone according to the design. Meanwhile, casing pipes were installed in the boreholes from top to the positions. After fixing the casing pipes, two boreholes were both drilled into the fault zone.

(3) Data collecting instruments in the observation borehole and water injection equipments in the injection borehole were installed as shown in Figure 6.

(4) Water injection test. Water was injected at several flow rates into $\mathrm{Br}-2$. Consecutive and longterm test cannot be allowed because of the driving inclined shaft. As a result of the limiting condition, four water injection tests were conducted as four injection cycles. During the water injection tests, the data were recorded every 20 seconds by the pressure measuring instrument and flow meter.

\section{RESULTS AND ANALYSES OF WATER} INJECTION TESTS IN THE FAULT

\subsection{RESULTS AND WATER SEEPAGE PROPAGATION BEHAVIOR OF WATER INJECTION TESTS}

Breakdown pressure and reopening pressure can be determined by the water injection tests in faults.
Generally, the breakdown pressure is determined according to the peak pressure during the first injection cycle, and the reopening pressure is interpreted as the pressure at which the borehole pressurization curve deviates from its sub-linear increasing trend during an injection cycle and can be taken from the average value following several cycles (Kang et al., 2010).

The injection water pressure and flow rate in $\mathrm{Br}$ 2 and observation water pressure in $\mathrm{Br}-1$ during the tests are shown in Figure 7. The injection water pressures were translated into the pressure that imposed in the fault zone due to the fact that the monitored injection pressure is the pressure at the orifice. A total of four water injection tests were conducted. For the first three, the flow rates were changed manually. And for the last one, the flow rate was held steady at a high rate.

The injection pressure in $\mathrm{Br}-2$ increases with the increasing flow rate at the outset of the first test (Fig. 7a), and the injection pressure reaches $5.05 \mathrm{MPa}$ when the flow rate is only $3.52 \mathrm{~L} / \mathrm{min}$. Then, the injection pressure falls to a stable value of about $4.5 \mathrm{MPa}$, whilst the flow rate reaches to $28.6 \mathrm{~L} / \mathrm{min}$ from $3.52 \mathrm{~L} / \mathrm{min}$. While, the observation pressure in $\mathrm{Br}-1$ does not change obviously during the first test, it just increases from $0.12 \mathrm{MPa}$ to $0.21 \mathrm{MPa}$. This result indicates that the permeability of the fault is low during the first test, and water may only flow through pore structure of fracture zone or the fine original cracks between $\mathrm{Br}-2$ and $\mathrm{Br}-1$, besides fine particulates and existing in-fill do not be washed out during the first test. In addition, the breakdown pressure is $5.05 \mathrm{MPa}$ from the curve.

Contrary to the first test, the observation pressure in Br-1 of the second (Fig. 7b) and third test (Fig. 7c) begins to increase in about 20 min under diminutive flow rates, while it increases from the start of the 


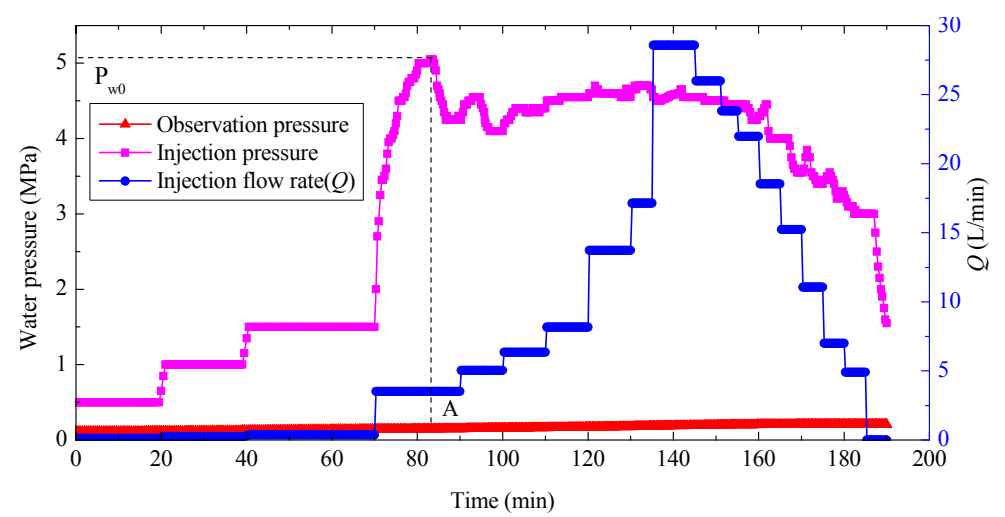

(a)

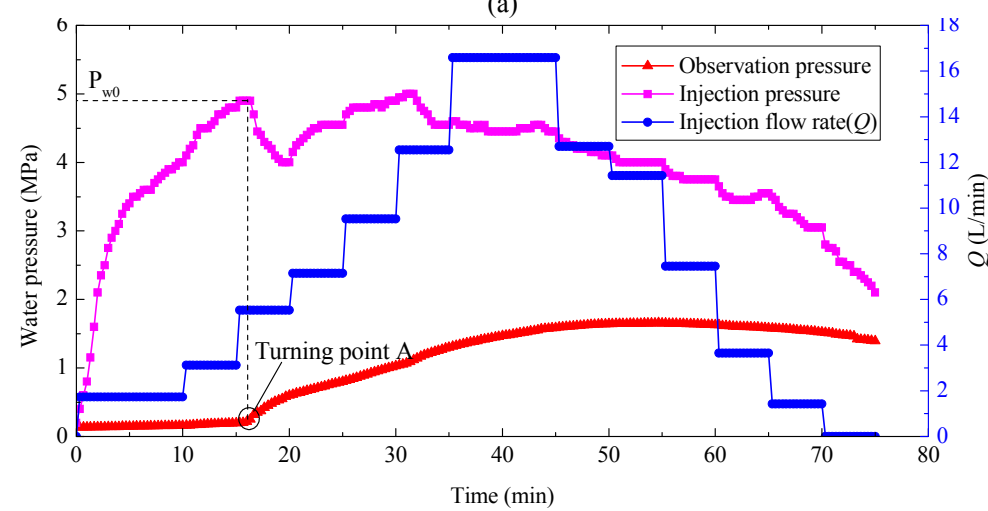

(b)

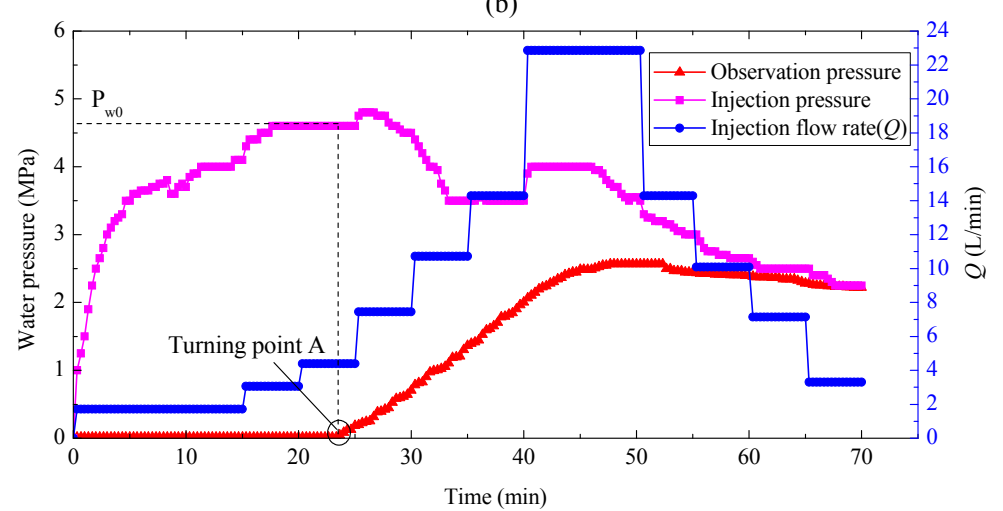

(c)

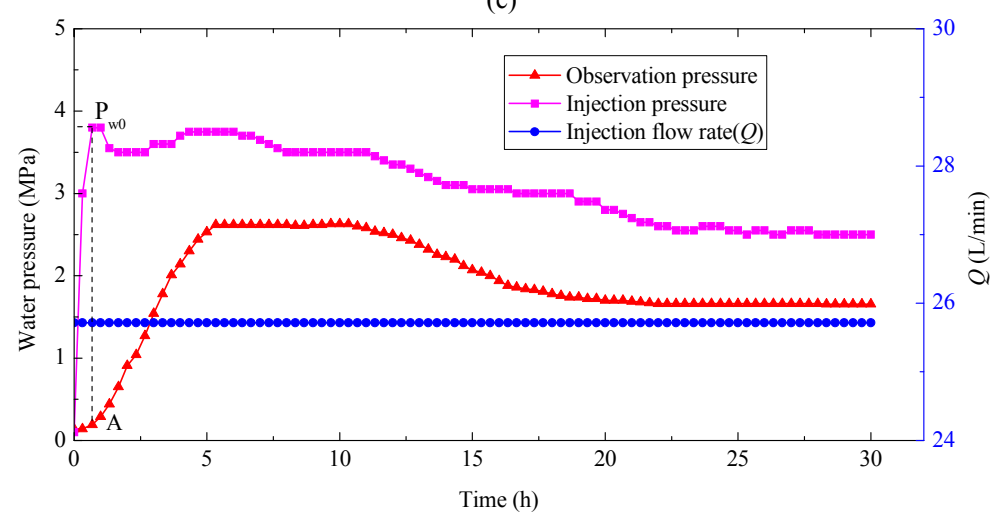

(d)

Fig. 7 Result curves of the water injection tests. a The first test. b The second test. $\mathrm{c}$ The third test. $\mathrm{d}$ The fourth test.

fourth test (Fig. 7d). When the observation pressure begins to increase, the injection pressure will drop. Moreover, similar curves are acquired from the second and third test. The observation pressure will maintain stable values for a period of time in the second (Fig. 7b) and third test (Fig. 7c), which indicates that water seepage in the fault is stable. During the fourth test, the observation pressure changes with the injection pressure, the difference between them consists in value (Fig. 7d). From the 
results of last three tests, we can obtain that the observation pressure will lag contrary to the injection pressure. Furthermore, the pressure at which the pressure curves of the last three tests deviate from their sub-linear increasing trend is $4.8 \mathrm{MPa}, 4.6 \mathrm{MPa}$ and $3.8 \mathrm{MPa}$, so the reopening pressure of the fault is 4.4 $\mathrm{MPa}$.

Water seepage propagation behavior in the fault can be analyzed from the curve of the observation pressure in Br-1 as well. Three stages of water seepage propagation in faults, from the whole injection test, can be discovered as pointed above. The first test may be considered as pore flow due to the low and changeless pressure. In the second and third test, a turning point in the observation pressure curve appears after the stage, and observation pressure rises up rapidly after the point. The observation pressure of the third test reaches a maximum of $2.56 \mathrm{MPa}$, which is greater than the maximum observation pressure obtained by the second test and similar to maximum observation pressure of the fourth test. During this process, fine particulates and existing in-fill in the fault are washed out and the original and newborn cracks are expanding and connecting, so the observation pressure rises up rapidly and this process may be considered as fracture flow. Then, the pressure remains stable for a short time and then declines. In this process, the water seepage channel in the fault is smooth and this stage may be turn into pipe flow. Therefore, the result of water injection tests can demonstrate the three stages of water seepage propagation behavior in faults further.

\subsection{ANALYSES OF IMPERMEABILITY OF THE FAULT}

1) The initial water seepage pressure and impermeability of the fault

Although the fault is much more permeable than complete rock stratum, its impermeability cannot be ignored. According to the results of water injection tests and analyses above, the turning point $\mathrm{A}$ is the start of fracture flow, as shown in Figure 4 and Figure 7, and the observation pressure changes observably after the point, the injection pressure corresponding to A point can be defined as the initial water seepage pressure $\left(\mathrm{P}_{\mathrm{w} 0}\right)$ (Fig. 7). Furthermore, the impermeability of faults can be calculated briefly from the equation as Eq. 1:

$\sigma_{a}=\frac{P_{w 0}}{R}$

where $P_{w 0}$ is initial water seepage pressure (MPa) and $R$ is the distance from the injection borehole to the observation borehole $(\mathrm{m})$ and it is $3.8 \mathrm{~m}$ due to the design. Thus, the impermeability $\left(\sigma_{a}\right)$ can be defined as the resistance of water seepage $(\mathrm{MPa} / \mathrm{m})(\mathrm{Wu}$ et al., 2003).

In the first test, $\mathrm{P}_{\mathrm{w} 0}$ is the peak pressure due to the stable observation pressure (Fig. 7a). As opposed to the first test, the observation pressure changes from the start of the fourth test (Fig. 7d). The calculated results are shown in Table 2. Where $P_{0}$ is the observation pressure $(\mathrm{MPa}), \Delta P$ is the water pressure differential between the injection pressure and the observation pressure (MPa).

According to the results (Table 2), the initial water seepage pressure $\left(P_{w 0}\right)$ has been decreasing from the first test to the last test $\left(P_{w 0}\right.$ varies from 5.05 $\mathrm{MPa}$ to $1.5 \mathrm{MPa})$, which indicates the impermeability will drop under the repeated water injection (Fig. 8). Puzizhier fault has a relatively high impermeability. The results can indicate that the structure of original Puzizhier fault is dense and has a relatively high impermeability.

In addition, in spite of the effect of former water injection test that has caused a kind of fracture flow or pipe flow in the fault, three stages of water seepage in the fault still exist in the next test (Figs. 7a, b and c), and it can be speculated that water seepage in the fault will turn into pipe flow after repeated water injection tests (Fig. 7d). In other words, the impermeability of the fault still exists and will decrease after repeated tests (Table 2). The reason for this is the fault healing effect under the ground pressure, and the fault cannot heal completely after repeated water injection tests. Moreover, the cognition can be obtained as well that the risk of water inrush through faults owes a great deal to the water source. When a water source with high pressure and giant flow rate gushes through the fault, the impermeability of the fault will decrease gradually and it is more dangerous.

\section{2) Relationship between flow rate $(Q)$ and injection pressure $(P)$}

The relationship between the flow rate and the injection pressure is a useful parameter to analyze the result of the injection tests (Jiang et al., 2007; Wu et al., 2003). The relationship between the flow rate and the injection pressure is shown in Figure 9. Ying (Ying et al., 2008) put forward three types of $Q-P$ relationship under high water pressure, e.g., Hydraulic fracturing, Expansion and Pervious laminar. For the Hydraulic fracturing, the flow rate increases rapidly when the pressure reaches initial water seepage pressure and shows low permeability. However, the initial water seepage pressure is not apparent for the type of Expansion. Hence, the tests of Puzizhier fault are classified into the type of Hydraulic fracturing (Fig. 9), indicating that the permeability of the fault is low.

Table 2 The results of impermeability of Puzizhier fault.

\begin{tabular}{llllc}
\hline \multirow{2}{*}{ Test } & \multicolumn{3}{c}{ Water pressure $(\mathrm{MPa})$} & \multirow{2}{*}{$\sigma_{a}$} \\
\cline { 2 - 4 } & $\mathrm{P}_{\mathrm{w} 0}$ & $\mathrm{P}_{\mathrm{o}}$ & $\triangle \mathrm{P}$ & $(\mathrm{MPa} / \mathrm{m})$ \\
\hline First & 5.05 & 0.15 & 4.9 & 1.33 \\
Second & 4.9 & 0.2 & 4.7 & 1.29 \\
Third & 4.6 & 0.14 & 4.46 & 1.21 \\
Fourth & 1.5 & 0.14 & 1.86 & 0.39 \\
\hline
\end{tabular}




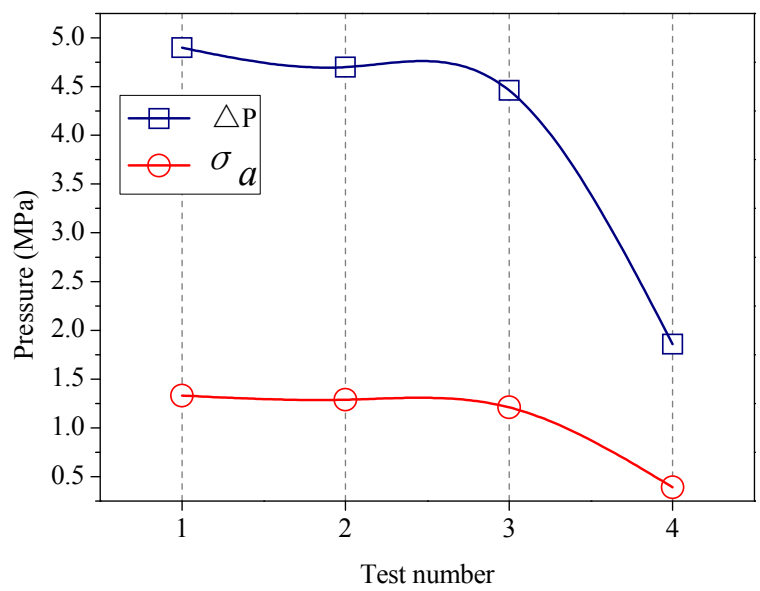

Fig. 8 The change processes of $\Delta P$ and $\sigma_{a}$.

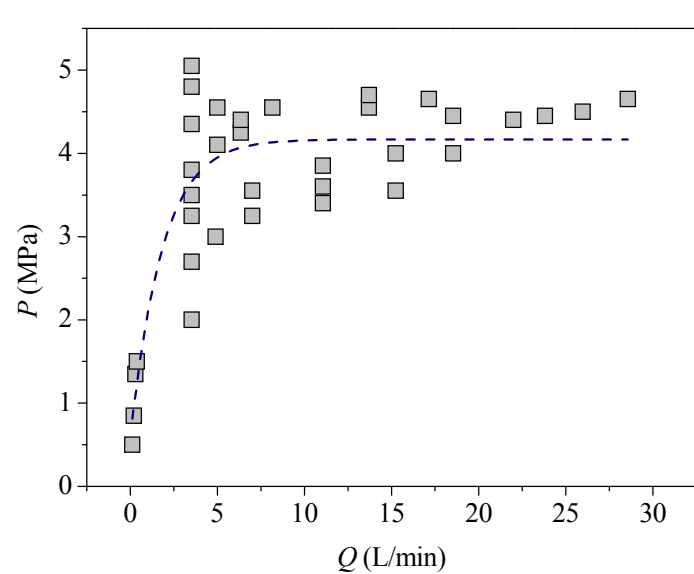

(a) The first test

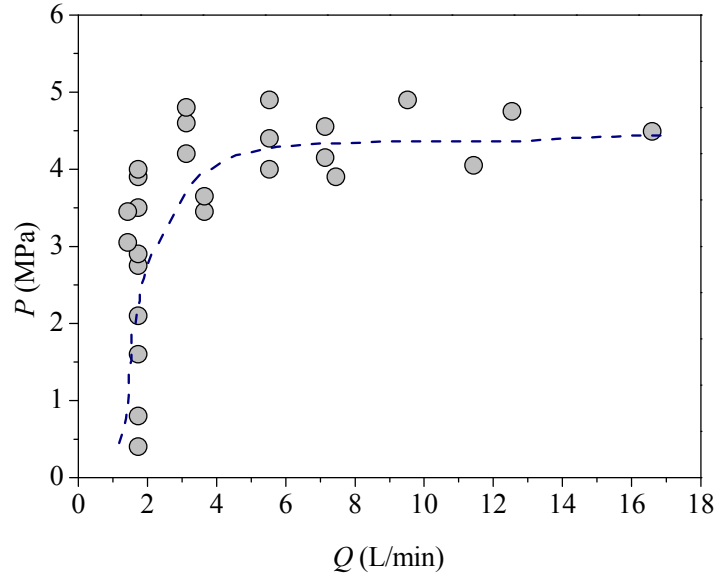

(b) The second test

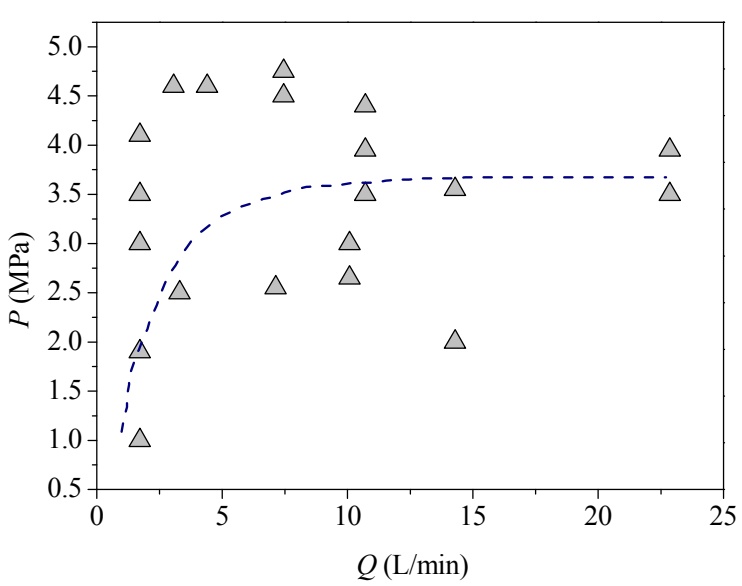

(c) The third test

Fig. 9 The relationship between the flow rate $(Q)$ and the injection pressure $(P)$.

\section{3) Initial hydraulic conductivity of the fault}

As mentioned above, pore flow exists in the process of water seepage in faults, indicating that the pore flow stage is Darcian flow, so the hydraulic conductivity of faults during that stage can be calculated using the Darcy's law. And a usual equation for the situation assuming steady-state laminar flow in homogeneous and isotropic media around the test borehole is used to calculate the hydraulic conductivity (Darcy, 1856; Sanchez et al., 2006; Hamm et al., 2007; Barbara et al., 2011):

$K=\frac{Q \ln \left(L / r_{w}\right)}{2 \pi L H_{0}}$

where $K$ is the hydraulic conductivity, $Q$ is the flow rate, $r_{w}$ is the radius of the borehole, $L$ is the length of the test section, and $H_{0}$ is the increase in head compare with that at rest. 


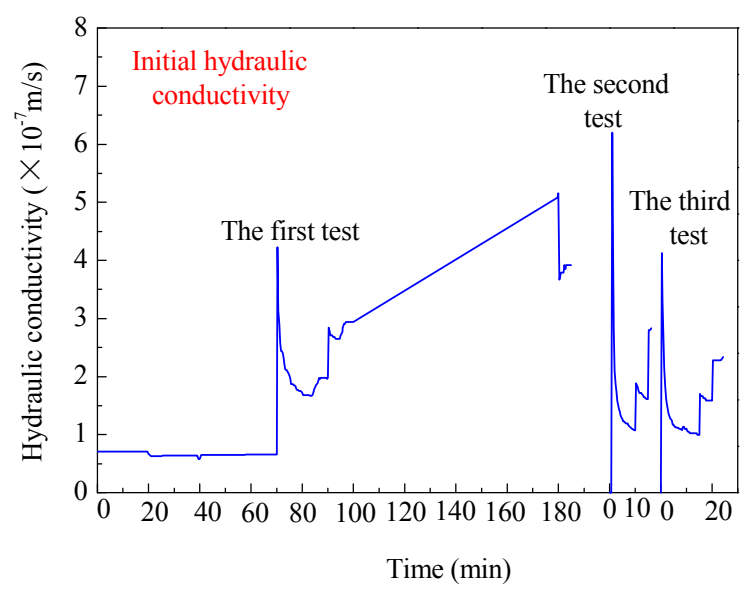

Fig. 10 Result of initial hydraulic conductivity $(K)$ of Puzizhier fault.

As shown in Figure 7, pore flow can be found in the first three tests. Consequently, the hydraulic conductivity of Puzizhier fault is calculated based on the data of water injection tests (Fig. 10). In general, the hydraulic conductivity results of Puzizhier fault are low, nearly all below $6.5 \times 10^{-7} \mathrm{~m} / \mathrm{s}$. As shown above, pore flow still exit in the prophase of the second and third tests, and the impermeability of the first, second and third tests could almost keep stable (Fig. 8). The hydraulic conductivity results are similar in the early stage of the second and third test and the first test (Fig. 10). Therefore, it can be considered as the initial hydraulic conductivity of Puzizhier fault. So, the initial hydraulic conductivity of Puzizhier fault is chiefly from $0.8 \times 10^{-7} \mathrm{~m} / \mathrm{s}$ to $6.5 \times 10^{-7} \mathrm{~m} / \mathrm{s}$.

\section{CONCLUSIONS}

Through the above study, conclusions can be drawn as follows:

1. Numerous water inrush accidents through fault will take some hours to reach the maximum water inflow, and three stages that consist of pore flow, fracture flow and pipe flow exist in the water inrush accident through faults, which show the water seepage propagation behavior in faults. The water inrush accidents through faults and the water injection tests may show the processes of the fine particulates and existing in-fill in the fracture zone washing out and the original and newborn cracks expanding and connecting.

2. According to the results of water injection tests in Xinglongzhuang coal mine, the breakdown pressure of Puzizhier fault is $5.05 \mathrm{MPa}$ and the reopening pressure is $4.4 \mathrm{MPa}$.

3. The initial water seepage pressure of Puzizhier fault is nearly $5 \mathrm{MPa}$ and its impermeability is higher than $1 \mathrm{MPa}$, which can be considered as the quantized impermeability value of Puzizhier fault. The impermeability of the fault will still exist due to the fault healing under the ground pressure, and cracks cannot heal completely after repeated water injection tests.
4. The risk of water inrush through faults owes a great deal to the water source. If the water is higher and the flow rate is greater, the risk of water inrush is higher.

5. The initial hydraulic conductivity of faults can be obtained based on the data of water injection test and the initial hydraulic conductivity of Puzizhier fault is chiefly from $0.8 \times 10^{-7} \mathrm{~m} / \mathrm{s}$ to $6.5 \times 10^{-7} \mathrm{~m} / \mathrm{s}$.

\section{ACKNOWLEDGMENTS}

The authors would like to deeply appreciate the support by the State Basic Research and Development Program of China (Grant No. 2013CB036003), the Construction Technology Project of Ministry of Transport of the People's Republic of China (Grant No. 2013318J12330), Innovation Project of Graduate Education for Jiangsu Province (KYLX_1401), the PAPD (A Project Funded by the Priority Academic Program Development of Jiangsu Higher Education Institutions), and the outstanding innovation $\mathrm{PhD}$ student scholarship of China University of Mining and Technology.

\section{REFERENCES}

Angulo, B., Morales, M., Uriarte, J.A. and Antiguedad, I.: 2011, Hydraulic conductivity characterization of a karst recharge area using water injection test and electrical resistivity logging. Engineering Geology 117, 90-96. DOI: 10.1016/j.enggeo.2010.10.008

Bai, H.B., Ma, D. and Chen, Z.Q.: 2013, Mechanical behavior of groundwater seepage in karst collapse pillars. Engineering Geology, 164, 101-106. DOI: $10.1016 /$ j.enggeo.2013.07.003

Bu, W.K. and Mao, X.B.: 2009, Research on effect of fault dip on fault activation and water inrush of coal floor. Chin. J. Rock. Mech. Eng., 28(2), 386-394.

Cheng, Y.U., Shih, M.H., Lin, B.C. and Gwo, F.L.: 2009, An empirical model for estimating hydraulic conductivity of highly disturbed clastic sedimentary rocks in Taiwan. Engineering Geology, 109, 213-223. DOI: $10.1016 /$ j.enggeo.2009.08.008

Darcy, H.: 1856, Les fountains publiques de la ville de dijion. Victor Dalmont, Paris. 
Feng, E.J. and Fu, M.Q.: 2004, Influence of fault activation on water inrush from roof of Coal Bed 3 in Dongtan mine. Coal. Geol. Explor., 4, 33-35.

Guo, Q.L., Ding, L.F., Wang, H.Z. and Zhang, Z.G.: 2003, Application research of high water pressure test for deep buried and pressuring chamber projects. Rock. Soil. Mech. 24(Suup), 99-102.

Hamm, S.Y., Kim, M., Cheng, J.Y., Kim, J.Y., Son, M. and Kim, T.W.: 2007, Relationship between hydraulic conductivity and fracture properties estimated from packer test and borehole data in a fracture granite. Engineering Geology, 92, 73-87. DOI: 10.1016/j.enggeo.2007.03.010

Huang, Z., Jiang, Z.Q., Zhu, S.Y., Qian, Z.W. and Cao, D.T.: 2014, Characterizing the hydraulic conductivity of rock formations between deep coal and aquifers using injection tests. Int. J. Rock. Mech. Min. Sci., 71, 12-18. DOI: 10.1016/j.ijrmms.2014.06.017

Jiang, Z.Q., Ji, L.J., Zuo, R.S., et al: 2002, Correl ativity among rock permeability and strain, stress under servo-control condition. Chin. J. Rock. Mech. Eng., 21(10), 1442-1446.

Jiang, Z.M., Fu, S., Li, S.G., et al.: 2007, High pressure permeability test on hydraulic tunnel with steep obliquity faults under high pressure. Chin. J. Rock. Mech. Eng., 26(11), 2318-2323.

Kang, H., Zhang, X., Si, L., et al.: 2010, In-situ stress measurements and stress distribution characteristics in underground coal mines in China. Engineering Geology 116, 333-345.

DOI: $10.1016 /$ j.enggeo.2010.09.015

Kitagawa, Y., Fujimori, K. and Koizumi, N.: 2007, Temporal change in permeability of the Nojima fault zone by repeated water injection experiments. Tectonophysics 443, 183-192. DOI: $10.1016 /$ j.tecto.2007.01.012

Li, L.J., Qian, M.G. and Li, S.G.: 1996, Mechanism of water inrush through fault. J. Chin. Coal. Soc., 21(2), 119123.

Li, Z.L., Shi, L.Q., Liu, T.B., et al.: 2006, Water-inrush mechanism of working face $51101 \mathrm{~W}$ in Liangzhuang coal mine. Coal. Geol. Explor., 34(5), 48-50.

Liu, Z.J. and Hu, Y.Q.: 2007, Solid-liquid coupling study on water inrush through faults in coal mining above confined aquifer. J. Chin. Coal. Soc., 32(10), 10461050.

Li, W.P., Liu, Q.M. and Sun, R.H.: 2011, Theoretical and experiment study on vadose conversion of water inrush later occurred from structure broken zone. Coal. Sci. Tech., 39(11), 10-13.

Lu, Y.L. and Wang, L.G.: 2013, Modeling and microseismic monitoring of damage and failure evolution of faulty coal seam floor. J. Min. Saf. Eng., 30(1), 38-44.

Meng, Z.P., Li, G.Q. and Xie, X.T.: 2012, A geological assessment method of floor water inrush and its application. Engineering Geology, 143-144, 51-60. DOI: $10.1016 /$ j.enggeo.2012.06.004

Mukai, A. and Fujimori, K.: 2007, Secular change of permeability in the fracture zone near the Nojima fault estimated using strain changes due to water injection experiments. Tectonophysics, 443, 193-199. DOI: $10.1016 /$ j.tecto.2007.01.023

Qiao, W., Hu, G. and Li, W.P.: 2013, Experimental study on the conversion from seepage to flow of water inrush aroused by fault activation. J. Min. Saf. Eng., 30(1), 30-37.
Quinn, P.M., Parker, B.L. and Cherry, J.A.: 2011, Using constant head step tests to determine hydraulic apertures in fractured rock. J. Contam. Hydrol., 126, 85-99. DOI: 10.1016/j.jconhyd.2011.07.002

Shi, L.Q. and Singh, R.N.: 2001, Study of mine water inrush from floor strata through faults. Mine. Water. Environ., 20, 140-147. DOI: 10.1007/s 10230-0018095-y

Sanchez, M.A., Foyo, A. and Tomillo, C.: 2006, Application of the Lugeon test in landfill hydrologic studies. Environ. Eng. Sci., 12(2), 125-136. DOI: $10.2113 / 12.2 .125$

Wang, Y., Yang, W.F., Li, M. and Liu, X.: 2012, Risk assessment of floor water inrush in coal mines based on secondary fuzzy comprehensive evaluation. Int. J. Rock. Mech. Min. Sci., 52, 50-55. DOI: $10.1016 /$ j.jirmms.2012.03.006

Wu, Q., Liu, J.T., Zhong, Y.P., et al.: 2002, Numeric simulations of water inrush time-effect on faults in Zhaogezhuang coal mine, Kailuan, China. J. Chin. Coal. Soc., 27(5), 511-516.

Wu, Q., Zhou, Y.J. and Liu, J.T.: 2003, Mechanical experimental study on lag mechanism of water inrush of fault under coal seam floor. J. Chin. Coal. Soc., 28(6), 561-565.

Wu, Q., Wang, M. and $\mathrm{Wu}, \mathrm{X} .:$ 2004, Investigations of groundwater bursting into coal mine seam floors from fault zones. Int. J. Rock. Mech. Min. Sci., 41, 557571. DOI: $10.1007 / \mathrm{s}$ 10230-013-0228-6

Wu, J.W.: 2003, Study on in-situ measurement of waterresisting ability of coal seam floor rock mass. Chin. J. Geotech. Eng., 25(1), 67-70.

Xu, D.J.: 2011, Advances in the research on mechanisms of the groundwater inrush caused by the fault reactivation in coalmines. Procedia. Eng., 26, 824831. DOI: 10.1016/j.proeng.2011.11.2243

Yang, S.A.: 1994, Prevention and control of water-inrush from faults in floor rocks in the workings. J. Chin. Coal. Soc., 19(6), 620-625.

Ying, L.M., Yang, C.H., Luo, C.W. and Wang, G.B.: 2005, Application of high water-pressure test to deep borehole. Rock. Soil. Mech., 26(10), 1692-1694.

Zheng, L.P., Yang, L.H. and Qi, Y.M.: 2010, Analysis of factors contributing to water inrush on Face 12012 in Liuzhuang Mine. Chin. Coal., 11, 91-94.

Zhou, R.G., Cheng, B.F., Ye, G.J., et al.: 2000, Time effect of water bursting in fault rupture zone. J. Eng. Geol., 8(4), 411-415.

Zhou, J., Mian, C., Yan, J. and Zhang, G.Q.: 2008, Analysis of fracture propagation behavior and fracture geometry using a tri-axial fracturing system in naturally fractured reservoirs. Int. J. Rock. Mech. Min. Sci., 45, 1143-1152.

DOI: $10.1016 /$ j.ijrmms.2008.01.001 